\title{
PERFORMANCE CRITERIA OF RUBBER UKM BASED ON COOPERATIVE USING BALANCED SCORECARD METHOD
}

\author{
Dessy Iriani Putri ${ }^{* 1}$, Lukman M. Baga*), and Burhanuddin*) \\ *) Departement of Agribusiness, Faculty of Economics and Management, Bogor Agricultural University \\ Kamper Road, Wing 4 Level 5 Campus of IPB Darmaga Bogor 16680
}

\begin{abstract}
Small and Medium Enterprises (UKM) of Usaha Mandiri is the only UKM in Putri Hijau district, North Bengkulu that carries out its activities based on cooperative principles. The UKM was established in 2010 due to the rubber farmer's concern about their future. In the last few years, the rubber price has declined, resulting in the decreasing performance of UKM Usaha Mandiri's. The objective of this research is to analyze the performance of UKM of Usaha Mandiri. The method used is balanced scorecard (BSC) and Focus Group Discussion (FGD) to identify the UKM's strategic aim and the BSC value. The result of the research shows that the performance of UKM of Usaha Mandiri started to decline from 2013-2015. The BSC score from 2011-2015 was 112.93 (excellent), 141.84 (excellent), 95.41 (excellent), 47.42 (average) and 81.62 (very good). The decline of the performance was due to the decline of natural rubber price. The conclusion for the research is that in 2015 the performance of UKM of Usaha Mandiri was categorized as very good (BSC method) with the most contribution from growth and learning perspective.
\end{abstract}

Keywords : Balanced scorecard, BSC, cooperation, performance measurement, UKM

\begin{abstract}
ABSTRAK
UKM Usaha Mandiri adalah satu-satunya UKM di Kabupaten Putri Hijau, Bengkulu Utara yang melakukan kegiatannya menggunakan prinsip-prinsip koperasi. UKM Usaha Mandiri didirikan pada tahun 2010 karena kekhawatiran yang dirasakan oleh beberapa anggota petani karet atas nasib mereka. Penurunan harga karet dalam beberapa tahun terakhir mengakibatkan kinerja UKM Usaha Mandiri menurun juga. Tujuan dari penelitian ini adalah untuk menganalisis kinerja UKM karet Usaha Mandiri. Metode yang digunakan adalah balanced scorecard (BSC) dan FGD untuk mengidentifikasi sasaran strategis UKM serta penentuan bobot BSC. Hasil penelitian ini menunjukkan bahwa kinerja UKM Usaha Mandiri mengalami penurunan sejak tahun 2013 hingga 2015. Skor BSC Usaha Mandiri dari tahun 2011-2015 adalah 112,92 (excellent), 141,84 (excellent), 95,41 (excellent), 47,42 (average), dan 81,62 (very good). Penurunan kinerja tersebut disebabkan oleh penurunan harga karet alam. Kesimpulan dari penelitian ini adalah kinerja UKM Usaha Mandiri mengunakan metode balanced scorecard pada tahun 2015 tergolong dalam kategori very good dengan perspektif yang paling berkontribusi adalah perspektif pertumbuhan dan pembelajaran.
\end{abstract}

Kata kunci: BSC, koperasi, pengukuran kinerja, UKM, karet

\footnotetext{
${ }^{1}$ Corresponding author:

Email:dessy.irianip@gmail.com
}

\section{INTRODUCTION}

Plantation subsector is one of the largest GDP contributors in Indonesia besides oil. One of Indonesia's main commodities is rubber. The potential development of rubber is shown by the land expansion for rubber plantation and partners development for strategic alliance in tire industry conducted by Indonesia government (Weerathamrongsak and Winai, 2013). Most of the rubber plantations in Indonesia are dominated by people owning plantation. The increase of rubber production is due to the increase of the rubber plantation area in Indonesia.

The increase of the rubber plantation did not instantly solve the problems faced by the rubber farmers. Problems that occur most are the wide area proportion of old rubber plantations, inefficiency of the marketing system in material production for rubber, limited capital to buy first grade plants and other means of productions 
such as fertilizers, herbicides, and limited availabilty of agriculture production for farmers (Siregar et al. 2012). The rubber farmers as the largest group of natural rubber producers in Indonesia, should be assisted and constructed in managing their rubber plantation. The role of an institution such as cooperation is greatly needed to establish and assist the rubber farmers in giving an additional value to the products and benefits to those who are involved in the process. According to ICA (2015), cooperation is a group of people who voluntarily get together to fulfill their economy, culture and social as well as inspiration needs through a company they own together and it controlled democratically.

UKM in Putri Hijau District, North Bengkulu is the only UKM that is cooperative based. The UKM was established in 2010 due to the concern of the rubber farmers in Desa Air Petai towards about their future. The price of rubber was fully controlled by the collectors because there was no any other place to sell. Based on this, then the farmers gathered and established a cooperative as a place to do agribusiness activities starting from providing rubber production means, preparing the agriculture tools and machine to selling the rubber production.

The success of UKM of Usaha Mandiri in increasing the welfare of the rubber farmers in Desa Air Petai is shown by the significant increase in their asset increase in 2010-2012. In the beginning of 2010, the asset of UKM was $\operatorname{Rp7,228,000~and~in~} 2012$ it reached 750,403,306. The problem is on the decrease price of rubber, lack of knowledge in cooperative policy, and lack of support from the local government. The price of rubber fell drastically, in 2011 with an average of Rp12,814 in 2012; Rp11,229 in 2013 about Rp10,514; and in 2014 Rp8,871 (Direktorat Jendral Perkebunan, 2015).

The problem in the rubber price resulted in the decline of the performance of UKM Usaha Mandiri performance. The decline causes the members to withdrew their voluntary deposits. There are also members who withdraw not only their voluntary deposit but also their obligatory deposit. This resulted in the decrease of the total number of members from 106 in 2011 to 78 in 2015 . The declining performance was shown by the selling of the cooperation's asset such as trucks, motorcycles, and agriculture tools and machine. In the meantime the selling of product was decreased because of decreased in the cash money, and customers who have not paid back their loan. Therefore, the decline of the performance should be evaluated to find out what aspect to increase.
One method that is used to evaluate an organization's performance is by using balanced score card method. The balanced scorecard plan can be used as a strategic controller for management to measure the success and failure of an organization (Susanti et al. 2012). The performance measurement uses 4 perspectives; financial, consumer, business process and learninggrowing (Kaplan and Norton, 2000). Customers' perspective presents the customers and market segment where the organization competed. Internal business process identified important processes to serve the customers and the organization owner. The growth and learning perspective presents the organization capability to create long term growth (Imelda, 2004).

Some researches using balanced scorecard were carried out Zulkarnaini (2012), Syamsiah et al. (2013), Surya (2014), Suryani et al. (2014) and Septiasari (2015). Zulkarnaini (2012) explained that the objectives of the balanced scorecard were derived from the vision and mission of the company's strategy. The use of balanced scorecard in strategy development was also used (Suryani et al. (2014). The outcome of the research was a statement by SEAMEO BIOTROP on its vision, mission, and strategy has four BSC perspectives. There are 31 strategic targets derived from four operational themes.

The balanced scorecard is also used in measuring the cooperative performance like in the research conducted by Syamsiah et al. (2013), Surya (2014), and Septiasari (2015). According to these researches, the performance measurement of the financial perspective includes CAR, current ratio, ROE and ROI. While the performance measurement of the customer perspective includes the degree of retention among the members and the degree of members' satisfaction. In addition, the performance measurement of the internal business perspective includes the number of business partners, business development, and the punctuality of loan disbursement. The performance measurement for growth and learning includes employees' workshop degree, productivity, and retention degree.

The result of the researches showed that the balanced scorecard can be used as comprehensive cooperative performance measurement method without leaving behind the financial aspect that motivates the cooperative development. In this regard, the objective of the research is to analyze Usaha Mandiri UKM rubber internal performance in the finance, customers, internal business, growth and learning using the balanced scorecard (BSC) method. 
The scope of the research covered the use of BSC in a cooperative. Although in the form of a UKM, the research object carries out its operation using the cooperative principles. Besides, in this research, the main data used for the performance measurement is are from the year of 2015 data and the year of 2011-2014 as comparison

\section{METHOD}

Data being collected are primary and secondary data. Primary data is the perception of the farmer members and employees on the satisfaction questionnaire, while the secondary data in this research are the UKM profile and finance data. The method being carried out is observations, interviews, questionnaires, and literature study.

In this research, from the UKM of Usaha Mandiri of the year 2016, seventy eight (78) customer members, three (3) employees, and two (2) convenient store employees were chosen as respondent. The data were analyzed descriptively and quantitatively. The descriptive analysis was used to present the UKM profile, interpret data and outcome of the interview. Balanced scorecard was used in analyzing the UKM of Usaha Mandiri performance.

In measuring the organization performance, the data analysis technique was based on supporting aid using balanced scorecard method consisting of: (1) determining the organization strategic goal and target (2) deciding target of each perceptions (3) defining the value of each perspective, (4) determining the outcome of target achievement of each perspective.

The strategic target decision was followed by the decision on the performance measurement, in this regard, calculating the organization performance score. The scores of the entire perspective were added up and compared in a scale of 100 which presented the UKM of Usaha Mandiri performance. To decide on the value, the paired comparison method was used on the four perspectives of balanced scorecard based on the importance or the effects on the strategies of UKM of Usaha Mandiri. The decision on the value was carried out using FGD (Focus Group Discussion) together with administration of the UKM of Usaha Mandiri.

The value of each indicator was obtained by determining the value of each indicator against the total value of the entire indicators using the formula:
Description:

$$
\partial i=\frac{X i}{\sum_{i-1}^{n} X i}
$$

$$
\begin{array}{lll}
\mathrm{Xi} & : & \text { variable score }-\mathrm{i} \\
\mathrm{I} & \mathrm{:} & \text { number of variable }
\end{array}
$$

While performance score was obtained from the multiplication of level of achievement with the decided value. The output of the total score measurement was compared in the scale of 100 . The scale points out the performance of UKM of Usaha Mandiri, as follow:

Table 1. Performance valuation scale

\begin{tabular}{ll}
\hline \multicolumn{1}{c}{ Score } & \multicolumn{1}{c}{ Performance valuation } \\
\hline $1 \leq \mathrm{x}<14.3$ & Reassign (R) \\
$14.3 \leq \mathrm{x}<28.6$ & Very poor (VP) \\
$28.6 \leq \mathrm{x}<42.9$ & Poor (P) \\
$42.9 \leq \mathrm{x}<57.2$ & Average (A) \\
$57.2 \leq \mathrm{x}<71.5$ & Good (G) \\
$71.5 \leq \mathrm{x}<85.8$ & Very good (VG) \\
$\mathrm{x} \geq 85.8$ & Excellent (E) \\
\hline
\end{tabular}

\section{RESULTS}

\section{UKM Usaha Mandiri Overview}

UKM of Usaha Mandiri is an UKM at Air Petani village, which is the largest village in Putri Hijau district, North Bengkulu. In the beginning, the UKM of Usaha Mandiri is Air Petai Village rubber farmers group that joined the Putri Hijau district farmers groups association (Gapoktan). Established in 1995, this farmer group was the origin and only farmers group in Air Petai village that has its activity on the people's rubber marketing. The people's rubber product was marketted in the form of cup lump. Beside its activity in marketing the people's rubber product, this group also provides extension services for the rubber farmers that enable the Usaha Mandiri farmers group to achieve their main objectives i.e. to increase the community income and create job opportunity in Air Petai village. "Usaha Mandiri" is a small-middle scale business (UKM), established in 12 February 2010 to fulfill the farmers group needs and business development, and the capital was obtained from Usaha Mandiri UKM farmer group. The UKM has a convenience store and transportation as their business activities. Due to the existence of the farmer group and Usaha Mandiri UKM, the Air Petai village community gradually is experiencing an economy developement because the UKM provides services directly to the surrounding community. The 
community joining the Usaha Mandiri farmers group, can get their daily necessities provided by the Usaha Mandiri convenience store without cash money or even got obtain a loan with their rubber land as a warranty.

In providing services to its members the Usaha Mandiri UKM uses bill/receipt system. On the date of 21 of each month, the Usaha Mandiri opens a new receipt, meaning that on that date the community can obtain their household necessities in the convenience store. An employee will record the amount of goods taken and calculate the total price. On the date of 22 of each month, the rubber product that belongs to the Usaha Mandiri farmer group member will be weight. The payment of the weighed product will be used to pay for the bill/receipt in the convenience store from the previous month. If the income is bigger than their loan, the rest of the money will be given to the person concerned, but if the income is lower than the receipt/bill, the deficit will be put into the bill/receipt of the following month. With this kind of system the community is benefited because they do not have to pay in cash to fulfill their daily necessities. When other rubber farmers converted or sold their rubber land because the rubber price keeps on decreasing, the Air Petai community can still preserve their rubber land as a warranty to the Usaha Mandiri UKM.

\section{Vision, Mission and Strategic Target}

The vision of Usaha Mandiri UKM is to make the Air Petai village community prosperous by increasing the community income and providing job opportunities. Meanwhile the missions are (1) developing the Air Petai rubber farmers through an extension program (2) marketing the Air Petai community rubber yield at a market price, and (3) fulfilling the Air Petai village community needs on rubber cultivation as well as their household necessities.

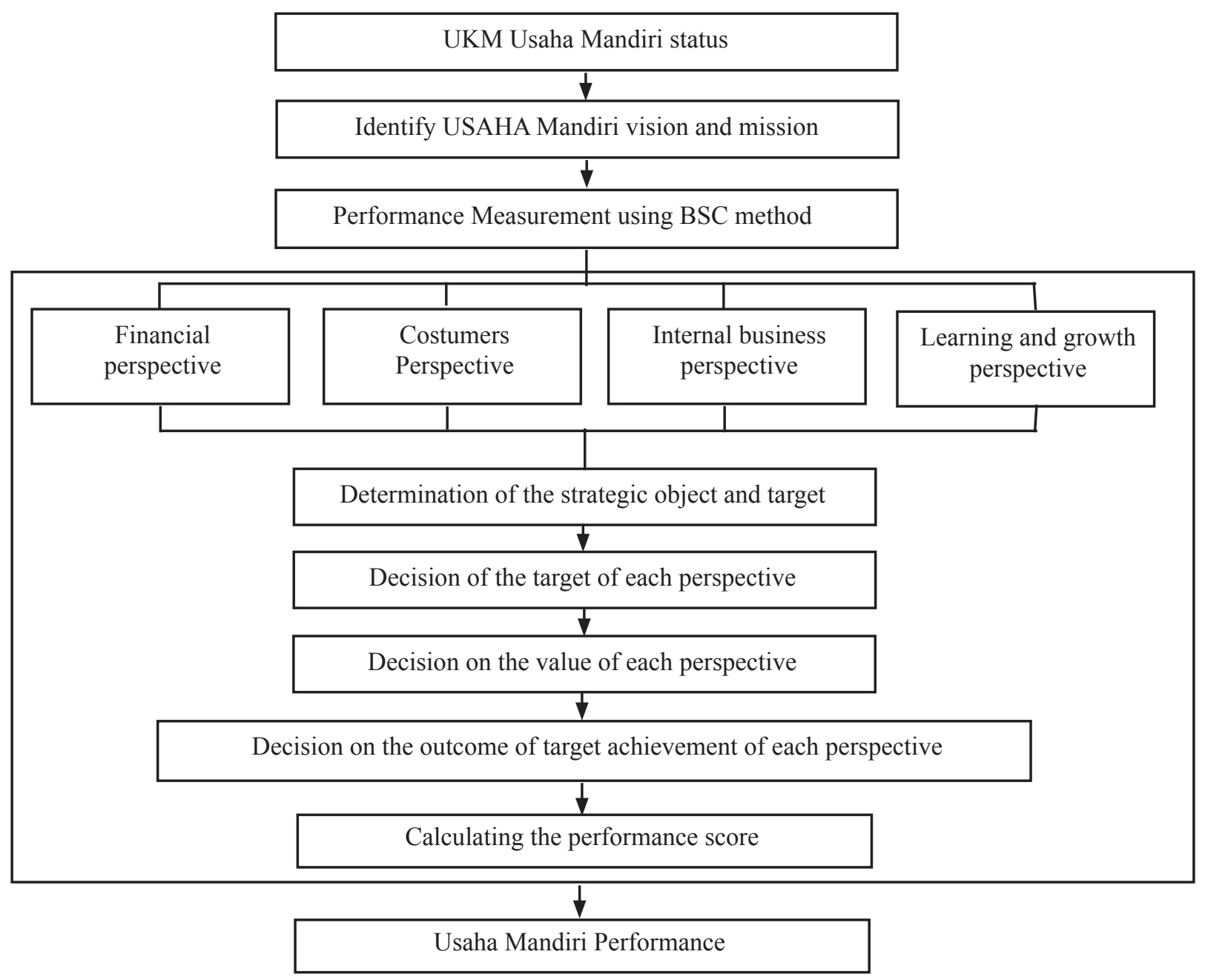

Figure 1. Research framework 
The strategic target of each balanced scorecard perspective was derived from the mission and vision of Usaha Mandiri UKM. Table 2 presents the Usaha Mandiri UKM strategic target performance value. The target of each perspective is:

1. Financial perspective: based on the vision statement of "to make the Air Petai village community prosperous by increasing the income ....", the strategic target implemented is to increase and enhance the assets and the business surplus.

2. Customer perspective: based on the vision statement of "to increase the income....," the strategic target implemented is to increase the total number of members, while increasing the customer the satisfaction is the strategy carried out to implement the mission statement of " to fulfill the community's necessities

3. Internal business perspective: based on the vision statement of "to increase the community income and create job opportunity..." the strategic target implemented is to develop the existing business, set up new business unit, and promote business partner.
4. Learning and growth perspective: based on the vision statement of "to create job opportunity ....." the implemented strategic target is to improve productivity and employees satisfaction and to increase the total number of employees.

\section{Weighting of Balanced Scorecard Perspective}

Weighting of balanced scorecard perspective shows the level importance of a perspective in Usaha Mandiri strategic formulation. Table 3 presents the result of the weighting of Usaha Mandiri UKM balanced scorecard perspective. Table 3 shows that, of the four perspectives, customer perspective has the highest importance level of $31.11 \%$. According to Usaha Mandiri UKM management, in running the cooperative-based UKM, customers are the subject being prioritized by the management. Similar to other cooperatives, the welfare of the customers (members) is the main objective in the establishment of Usaha Mandiri. According to the management, without the presence of members, Usaha Mandiri will not exist. Furthermore, from the customer perspective, the strategic target that has the highest importance level is the customer satisfaction i.e. $18.15 \%$.

Table 2. BSC strategic target performance achievement of Usaha Mandiri UKM

\begin{tabular}{lll}
\hline & \multicolumn{1}{c}{ Strategic target } & \multicolumn{1}{c}{ Performance criteria } \\
\hline & Financial Perspective (F) & Current Ratio \\
\hline F1 & Increasing and developing the Usaha Mandiri UKM assets & Total Debt to Total Asset \\
F2 & & Return on Asset \\
F3 & Increasing the income and business surplus & \\
& Customer Perspective (C) & Member customer growth \\
C1 & Increasing the total number of Usaha Mandiri UKM member customers & Customer satisfaction level \\
C2 & Increasing the Usaha Mandiri UKM member customer satisfaction & \\
& towards the employee performance & \\
& Internal Business Perspective (B) & \\
B1 & Developing the existing business and setting up a new business unit & Total number of business unit \\
B2 & Promoting Usaha Mandiri UKM business partner & Total number of business partner \\
& Growth and Learning Perspective (G) & \\
G1 & Increasing employee productivity & Earning per hour \\
G2 & Improving employee satisfaction & Employee satisfaction level \\
G3 & Increasing total number of employee & Employee retention level \\
\hline
\end{tabular}


Table 3. The result of the weighting of balanced scorecard perspective

\begin{tabular}{lc}
\hline \multicolumn{1}{c}{ Output criteria } & Weight (\%) \\
\hline Financial Perspective & 15.56 \\
F1 Curent Ratio & 5.76 \\
F2 Total Debt to Total Asset & 4.61 \\
F3 Return on Asset & 5.19 \\
Customer Perspective & 31.11 \\
C1 Customer members growth & 12.96 \\
C2 Customer satisfaction & 18.15 \\
Internal Business perspective & 26.67 \\
B1 Total number of business partner & 11.11 \\
B2 Total number of business unit & 15.56 \\
Growth and learning perspective & 26.67 \\
G1 Employee retention & 6.91 \\
G2 Employee productivity & 9.88 \\
G3 Employee satisfaction & 9.88 \\
\hline
\end{tabular}

\section{Performance Score Calculation}

The performance score using the balanced score card approach was the result of a multiplication between target achievement with the value The performance score showed the size of a perspective contribution and strategic target unto the Usaha Mandiri UKM performance. The result of Usaha Mandiri UKM performance score calculation is presented in Table 4. Usaha Mandiri UKM performance as seen from four perspectives, i.e. Financial, customers, internal business, growth and learning perspectives were categorized very well because the balanced scorecard total is between 71.5 and 85.8 .

The biggest contribution to the Usaha Mandiri UKM performance in year 2015 is from the growth and learning perspective with the score of 52.11. The high score was due to the high employee productivity. In year 2015 the Usaha Mandiri UKM employee productivity reached Rp12.060/hour, while the target was only Rp4.000/hour.

The lowest perspective that contributed to the Usaha Mandiri UKM performance in year 2015 was the customer perspective that scored 0.63 . The low score of the customer perspective is because there was a decrease in the total number of members and the customer satisfaction did not reach the target. Based on the balanced scorecard score in Table 3, the perspective that needs attention from the Usaha Mandiri UKM to develop its performance is customer perspective. This is because the customer perspective has the highest value but it got the lowest score. The biggest value showed that the customer perspective was prioritized more compared to other perspectives, so that to improve the performance in the following year, the Usaha Mandiri UKM has to increase the number of the UKM member.

Compared to the previous four years, the Usaha Mandiri UKM performance experienced a decrease (Figure 2.) The graph showed that the best or highest Usaha Mandiri UKM performance happened in year 2012. The high performance Usaha Mandiri was due to the high rubber price in that year, reaching Rp22,000/kg. The high performance in 2012, had made Usaha Mandiri achieve a platinum award from the Ministry of Social. With the decreased of the rubber price in 2013, the performance of the Usaha Mandiri had also decrease until 2014, and during that time the rubber price received by the farmers was only about $\mathrm{Rp} 5,000 / \mathrm{kg}$, and this affected the performance in 2014 that decreased drastically.

In 2015, the Usaha Mandiri performance was getting better although it experienced an increase but not as good as in year 2011-2013. The increased performance in 2015 was affected by the price of the rubber reaching $\mathrm{Rp} 7,000 / \mathrm{kg}$. Another other factor that influenced the performance in 2015 was a defensive effort that was implemented by the Usaha Mandiri UKM, in the form of selective action in the availability of goods stock for the convenience store. In the period of 2011-2014, Usaha Mandiri avail the whole household necessities in big amount, although they were not urgent goods, such as slippers, toys, snacks, brooms and child toothbrushes. In 2015, Usaha Mandiri stopped the purchase of the goods, so that it can reduce the cost and increase the income a little.

Another effort taken by Usaha Mandiri to survive is a progressive loan. If in year 2011-2014 members can could have an unlimited loan, this time it was given as a progressive loan so that Usaha Mandiri will still have savings or deposits so that it will not face bankruptcy Loan given was different for each member depending on the rubber product they have. The more rubber product sold to the UKM monthly, the bigger loan the member can get or the other way round.

This effort could not be maintained by Usaha Mandiri for long; therefore, another effort should be carried out to satisfy the members. Another effort that can be done by Usaha Mandiri UKM is to open a new bigger unit, such as Ribbed Smoke Sheet processing. At the time, the Usaha Mandiri UKM had only market the farmers' rubber in the form of cup lump to the plant. With the 
available empty land in the UKM vicinity and simple RSS processing, Usaha Mandiri UKM can process the member farmers' latex into RSS. Processing latex into RSS will give a big profit to the UKM, because the price of RSS is higher and stable compared to cup lump. As shown in Table 3, the business unit has a big priority, and there will be a possibility that by opening a new business unit such as the RSS processing, this will increase the Usaha Mandiri UKM performance. This is in accordance with the research result of Huang et al. (2004) that mentioned with the development of new business unit, it is expected that the income and revenue of the rubber cooperation will increase.

Table 4. The result of Usaha Mandiri UKM performance criteria using balanced scorecard method of Year 2015

\begin{tabular}{|c|c|c|c|c|c|}
\hline Result criteria & $\begin{array}{l}\text { BSC Value } \\
\text { (a) }\end{array}$ & $\begin{array}{l}\text { Target } \\
\text { (b) }\end{array}$ & $\begin{array}{l}\text { Realization } \\
\text { (c) }\end{array}$ & $\begin{array}{l}\text { Target } \\
\text { Achieved } \\
\text { (c:d) }\end{array}$ & $\begin{array}{c}\text { Score } \\
((\mathrm{c}: \mathrm{d}) \mathrm{x} a)\end{array}$ \\
\hline \multicolumn{6}{|l|}{ Financial perspective } \\
\hline Curent ratio & $5,76 \%$ & $200 \%$ & $119 \%$ & $60 \%$ & 3,43 \\
\hline Total debt to total asset & $4,61 \%$ & $30 \%$ & $54,99 \%$ & $54,56 \%$ & 2,52 \\
\hline \multirow[t]{2}{*}{ Return on asset } & $5,19 \%$ & $10 \%$ & $3,51 \%$ & $35,10 \%$ & 1,82 \\
\hline & $15,56 \%$ & & & & 7,77 \\
\hline \multicolumn{6}{|l|}{ Customer perspective } \\
\hline Growth customer members & $12,96 \%$ & $10 \%$ & $-11 \%$ & $-110 \%$ & $-14,26$ \\
\hline \multirow[t]{2}{*}{ Customer satisfaction } & $18,15 \%$ & $100 \%$ & $82 \%$ & $82 \%$ & 14,88 \\
\hline & $31,11 \%$ & & & & 0,63 \\
\hline \multicolumn{6}{|l|}{ Internal business perspective } \\
\hline Total number of business partner & $11,11 \%$ & 2 & 1 & $50 \%$ & 5,56 \\
\hline \multirow[t]{2}{*}{ Total number of business unit } & $15,56 \%$ & 1 & 1 & $100 \%$ & 15,56 \\
\hline & $26,67 \%$ & & & & 21,12 \\
\hline \multicolumn{6}{|l|}{ Growth and learning Perspective } \\
\hline Employee retention & $6,91 \%$ & $-20 \%$ & $-40 \%$ & $200 \%$ & $13 ., 82$ \\
\hline Employee productivity & $9,88 \%$ & Rp 4.000 & Rp 12.060 & $301,51 \%$ & 29,79 \\
\hline \multirow[t]{3}{*}{ Employee satisfaction } & $9,88 \%$ & $100 \%$ & $86 \%$ & $86 \%$ & 8,50 \\
\hline & $26,67 \%$ & & & & 52,11 \\
\hline & tal Score & & & & 81,62 \\
\hline
\end{tabular}

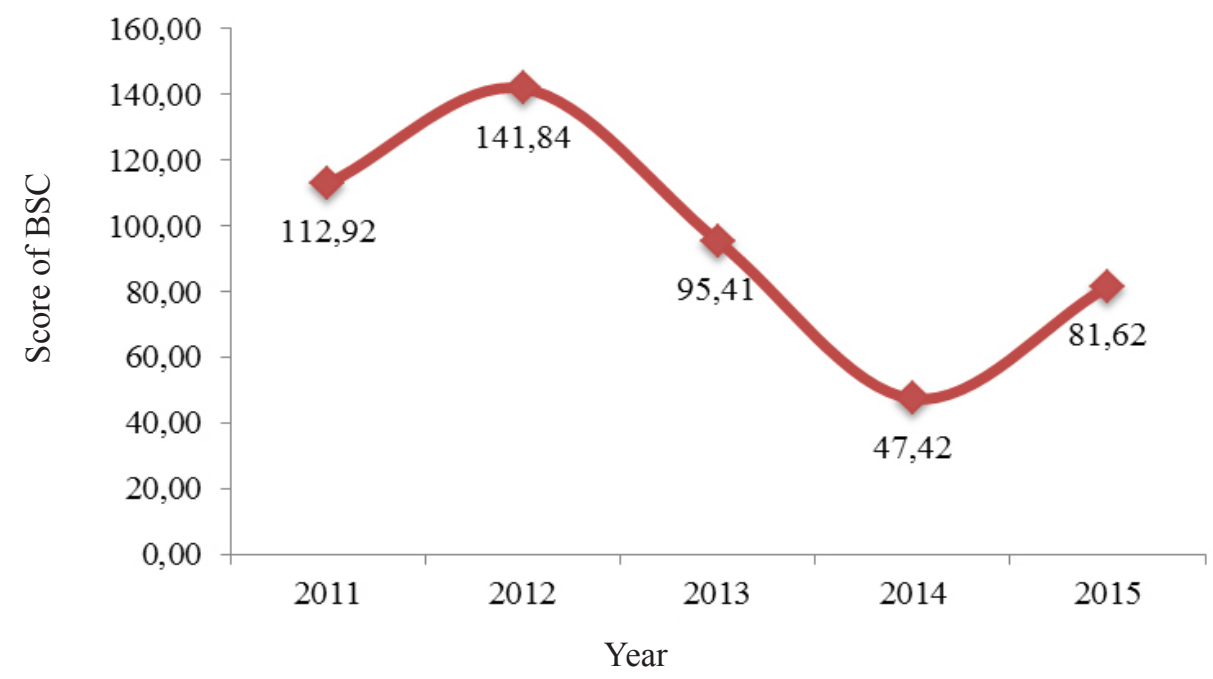

Figure 2. Usaha Mandiri UKM performance scale year 2011-2015 


\section{Managerial Implications}

With the performance criteria using the balanced scorecard, Usaha Mandiri UKM is able to know the steps that have to be taken to develop its business in the future. This is because the output of the balanced scorecard showed the perspective that contributed the lowest so that Usaha Mandiri UKM can fix it. The perspective that contributed the lowest score at the balanced scorecard and caused the decreases of Usaha Mandiri perspective was the customer perspective.

The customer perspective had the lowest score, indicating that the UKM performance decreased due to the customer perspective, especially in the customer member growth aspect. This should be observed by the Usaha Mandiri UKM because if looking at the value, this perspective has the biggest value, meaning that this perspective is highly prioritized compared to the other perspectives Based on this, the first thing that should be done by the Usaha Mandiri UKM in increasing its performance is by promoting again the Usaha Mandiri UKM so that any Air Petai village rubber farmer who has not joined or has left is interested to in becoming a member of the UKM. But, if it is difficult to do, another alternative is for the Usaha Mandiri UKM to optimize the employees' service to the remaining members, so that the members' satisfaction will be maximum and their loyalty to Usaha Mandiri will also increase. Looking at the highest score, the perspective that should be maintained by the Usaha Mandiri UKM is the growth and learning perspective, especially the employee productivity aspect. Based the on the balanced scorecard, employee productivity that is calculated hourly has exceeded the target set by the Usaha Mandiri UKM management. This showed that the performance of the employees of Usaha Mandiri UKM is already very good; therefore, an additional aspect for the employee is not needed, so that the Usaha Mandiri UKM can more focus on the customer and financial aspects.

\section{CONCLUSIONS AND RECOMMENDATIONS}

\section{Conclusions}

The conclusion obtained from the research using balanced scorecard is that the Usaha Mandiri UKM performance experienced a decrease from 2013 to 2015 Based on the balanced scorecard analysis, the reason for the performance decrease is due to the number of members who quit from the UKM, as the showed in the low score in the balanced scorecard in the customer perspective especially in the member growth aspect while the perspective that contributed the biggest to the Usaha Mandiri UKM performance is the growth and learning perspective especially on the employee productivity aspect.

\section{Recommendations}

The Usaha Mandiri UKM should maintain its employee's productivity and increase and enhance the number of its member in the following year to increase the performance. For the upcoming research, similar study needs to be carried out in other rubber cooperatives in Indonesia as a comparer and analysis on factors that affect the rubber cooperation performance so that strategies in the rubber cooperative development in Indonesia can be formulated.

\section{REFERENCES}

Direktorat Jendral Perkebunan. 2015. Statistik Perkebunan Indonesia 2014-2016: KARET. Jakarta: Direktorat Jendral Perkebunan.

Huang H, Zhang W, Zhang X, Huang Ha. 2014. The current sittuation and development strategies of rubber farmer cooperatives in Hainan Province. Asian Agricultural Reasearch 6(5): 102-104.

ICA [International Co-operative Alliance]. 2015. What is a co-operative?. http://ica.coop. [14 Desember 2015].

Imelda RHN. 2004. Implementasi balanced scorecard pada organisasi publik. Jurnal Akuntansi \& Keuangan 6(2): 106-122.

Kaplan RS, Norton DP. 2000. Balanced scorecard Menerapkan Strategi Menjadi Aksi. Pasla PR, penerjemah; Sumiharti Y, Kristiaji WC, editor. Jakarta: Erlangga.

Septiasari MI. 2015. Balanced scorecard sebagai pengukuran kinerja koperasi perikanan segaraning harum Kabupaten Badung. [tesis]. Denpasar: Universitas Udayana.

Surya LPLS. 2014. Analisis kinerja berbasis balanced scorecard pada koperasi XYZ. Jurnal Akutansi Universitas Udayana 8(2): 279-293.

Siregar H, Sitorus SRP, Sutandi A. 2012. Analisis potensi pengembangan perkebunan karet rakyat di Kabupaten Mandailing Natal, Provinsi Sumatera Utara. Forum Pascasarjana 35(1): $1-13$.

Suryani D, Syarif R, Suroso AI. 2014. Perancangan 
balanced scorecard untuk pengembangan strategi di Sameo Biotrop. Jurnal Manajemen \& Agribisnis 11 (1): 33-40.

Susanti I, Hubeis AV, Kuswanto S. 2012. Perancangan manajemen kinerja penyelenggaraan pendididikan dan pelatihan dengan ancangan Management by Objectives (MBO) dan perspektifbalanced scorecard.JurnalManajemen \& Agribisnis 9 (1): 43-58.

Syamsiah NF, Rodhiyah. 2013. Analisis pengukuran kinerja organisasi dengan metode balanced scorecard. Diponegoro Journal of Social and Politic 2013:1-10.
Weerathamrongsak P, Wongsurawat W. 2013. The rubber industry of Thailand: a review of past achievements and future prospects. Journal of Agribusiness in Developing and Emerging Economies 3 (1): 49-61. https://doi. org/10.1108/20440831311321665.

Zulkarnaini. 2012. Pengaruh penerapan perbaikan proses bisnis internal dan tanggung jawab sosial perusahaan terhadap Kinerja bank dengan pendekatan balanced scorecard (Sensus pada Bank Umum di Wilayah Kota Banda Aceh). Keuangan dan Bisnis 4 (3): 249. 